\title{
Determinan Tax Avoidance Pada Industri Barang Konsumsi Tahun 2014-2018
}

\author{
Elvina Dwi Anita ${ }^{1 *}$, Kartika Hendra Titisari ${ }^{2}$, Siti Nurlaela ${ }^{2}$ \\ ${ }_{1,2,3}$ Program Studi Akuntansi Fakultas Ekonomi, Universitas Islam Batik Surakarta \\ *Correspondence email: vinaanita31@gmail.com
}

\begin{abstract}
Taxes are the country's biggest income support but are against the interests of companies that consider taxes to be a deduction from income. Differences in interests have caused many tax avoidance cases to minimize tax payments. The purpose of this study was to analyze the influence of independent commissioners, audit committees, capital intensity, leverage, profitability, and advertising costs on tax avoidance. The consumer goods industry on the Indonesia Stock Exchange in the 2014-2018 period, 38 companies were made into populations. The use of a purposive sampling technique produced 23 sample companies with 115 observational data. The data analysis technique uses panel data regression with selected random effect models. The results of the study prove that leverage and profitability affect tax avoidance, while independent commissioners, audit committees, capital intensity, and advertising costs do not show an effect on tax avoidance.
\end{abstract}

\section{Keywords: Capital Intensity; GCG; Leverage; Profitability; Tax Avoidance}

\section{PENDAHULUAN}

Pendapatan sektor pajak masih menjadi penopang utama perekonomian Indonesia. Berdasarkan laporan kinerja kementerian keuangan 79,84 \% dari jumlah penerimaan negara ditahun 2018 sebesar Rp. 1.64,2 triliun masih didominasi dari penerimaan pajak senilai Rp. 1.315,93 triliun. Tingginya potensi penerimaan dari lingkup perpajakan tidak diimbangi dengan kesadaran dalam pembayaran pajak sehingga belum mampu memenuhi target APBN, seperti data yang termuat dalam Tabel 1 berikut ini:

Tabel 1

Presentase Realisasi Penerimaan Pajak di Indonesia

\begin{tabular}{llcl}
\hline Tahun & Target & Realisasi & Capaian \\
\hline 2014 & $1.072 .376,36$ Miliar & $985.129,79$ Miliar & $91,86 \%$ \\
2015 & $1.294 .258,67$ Miliar & $1.060 .860,57$ Miliar & $81,97 \%$ \\
2016 & $1.355 .203,52$ Miliar & $1.105 .974,44$ Miliar & $81,60 \%$ \\
2017 & $1.283 .565,86$ Miliar & $1.151 .130,09$ Miliar & $89,68 \%$ \\
2018 & $1.423 .995,49$ Miliar & $1.313 .507,25$ Miliar & $92,24 \%$ \\
\hline
\end{tabular}

Sumber: Direktorat Jenderal Pajak (2019)

Data diatas membuktikan bahwa upaya optimalisasi potensi penerimaan pajak dari tahun ke tahun belum pernah mencapai target, meskipun besarnya nominal realisasi penerimaan selalu mengalami peningkatan setiap tahunnya. Penurunan tarif pajak hingga pengampunan pajak (tax amnesty) dilakukan pemerintah dalam rangka memaksimalkan target penerimaan. Namun realitanya, anggapan mengenai pajak yang mengurangi pendapatan perusahaan masih sering dijumpai. Sehingga banyak dilakukan upaya untuk memanfaatkan kelemahan dalam UU dan peraturan perpajakan secara absah guna meminimalisir beban pajaknya atau lebih dikenal sebagai tindakan tax avoidance. Tax avoidance (penghindaran pajak) menurut Riantami \& Triyanto, (2018) sebagai tindakan legal yang tidak melanggar hukum dengan memanfaatkan celah atau kelemahan dalam ketentuan perpajakan. Tahun 2016 posisi 11 dari 30 negara ditempati Indonesia dengan penghindaran pajak mencapai 6,48 miliar dolar AS sebagaimana laporan survei dari Ernesto Crivelly yang kemudian dianalisa lagi oleh Universitas PBB (www.Tribunnews.com). Bukti adanya temuan tindakan tax avoidance diantaranya tahun 2014 PT Coca Cola Indonesia diduga bertindak curang dengan melebihkan jumlah biaya iklan hingga mengakibatkan kerugian yang ditanggung negara. Ditemukannya pembengkakan biaya sebesar Rp566,84 miliar dari rentang waktu tahun 2002 - 2006 mengarah pada tindakan penghindaran pajak. (www.kompas.com). Lembaga Tax Justice Network di tahun 2019 melaporkan PT Bentoel Internasional Investama Tbk selaku anak perusahaan British American Tobacco (BAT) atas adanya dugaan praktek penghindaran pajak. Skema yang dilakukan dengan pembayaran bunga utang melalui internal perusahaan serta pembayaran royalti, ongkos dan biaya IT. Taktik ini dilakukan dengan mengalihkan transaksi melalui anak perusahaan BAT yang berada di negara yang melakukan kesepakatan perpajakan dengan Indonesia. Atas skema tersebut kerugian yang ditanggung pemerintah mencapai 14 juta dolar AS per tahun. (www.nasional.kontan.co.id) 
Beberapa bukti diatas menunjukkan undang-undang perpajakan nyatanya masih dinilai memiliki kelonggaran hukum yang dalam penerapannya banyak ditemukan kasus perusahaan memanfaatkan kelemahan peraturan pajak. Beberapa faktor yang mempengaruhi terjadinya tindakan tax avoidance diantaranya Good Corporate Governance (GCG) dengan proksi komisaris independen \& komite audit, capital intensity, leverage, profitabilitas dan beban iklan diuji dalam penelitian ini. Penelitian tentang faktor penentu tindakan penghindaran pajak telah banyak dilakukan dan menunjukkan beragam hasil. Alfina, et al., (2018) membuktikan adanya pengaruh komisaris indepeden pada tax avoidance, sedangkan temuan Syamsuddin \& Suryarini, (2019) tax avoidance tidak dipengaruhi oleh komisaris indepeden. Lestari et al., (2018) menemukan komite audit mempengaruhi tax avoidance, lain dengan bukti penelitian dari Praditasari \& Setiawan (2017) bahwa tax avoidance tidak dipengaruhi komite audit. Anindyka et al., (2018) membuktikan bahwa capital intensity mempengaruhi penghindaran pajak sementara temuan Syamsuddin \& Suryarini, (2019) tax avoidance tidak dipengaruhi capital intensity.

Praditasari \& Setiawan (2017) memberikan bukti bahwa leverage berpengaruh pada tax avoidance, sedangkan Anindyka, et al., (2018) menunjukkan hasil yang sebaliknya. Hasil bahwa tax avoidance dipengaruhi profitabilitas sebagaimana temuan Astuti, et al., (2018), sementara Puspita, et al., (2018) membuktikan profitabilitas tidak berpengaruh pada tax avoidance. Sugitha \& Supadmi (2016) menemukan adanya pengaruh beban iklan terhadap penghindaran pajak, lain dengan Novitasari \& Suharni (2019) bahwa beban iklan tidak berpengaruh pada tax avoidance. Berdasarkan laporan kinerja kementerian perindustrian tahun 2018 mengenai industri pengolahan non migas yang menyumbangkan kontribusi sebesar 17,63\% terhadap PDB sekaligus menunjukkan bahwa industri tersebut memiliki peranan besar dalam pembayaran pajak di Indonesia. Sehingga penelitian ini berfokus pada sektor industri barang konsumsi. Yang membedakan penelitian ini dibandingkan penelitian yang telah ada sebelumnya yaitu kombinasi variabel independen dari penelitian sebelumnya yang belum konsisten, populasi perusahaan yang digunakan serta periode pengamatan. Berlandaskan konteks yang telah diuraikan, maka peneliti bermaksud untuk menguji dan menganalisis kembali tentang tax avoidance apakah dipengaruhi komisaris independen, komite audit, capital intensity, leverage, profitabilitas dan beban iklan pada industri barang konsumsi di BEI tahun 2014-2018.

\section{Literatur Review dan Pengembangan Hipotesis}

Teori Keagenan

Dijabarkan bagaimana jalinan antara pemilik selaku principal dan manajer sebagai agent dalam hal pengelolaan perusahaan memiliki kepentingan yang berbeda. Hal tersebut memicu untuk berperilaku serta bertindak sesuai kepentingan pribadi (Dewinta dan Setiawan, 2016). Masalah agensi terjadi ketika adanya perbedaan pelaporan antara laba komersial dan laba fiskal bahwa manajer menyajikan laporan keuangan yang tidak sesuai keadaan semestinya. Yorke, et al., (2016) menambahkan bahwa manajer akan terdorong bertindak dengan cara yang akan mengurangi nilai klaim atas pemegang saham sambil memaksimalkan keuntungan pribadinya.

\section{Tax Avoidance}

Riantami \& Triyanto, (2018) menjelaskan bahwa tindakan tax avoidance sebagai upaya menghindari pajak yang dilakukan secara aman dan legal dengan memanfaatkan celah atau kelemahan dalam ketentuan perpajakan yang mengarah pada pengenaan bukan objek pajak.

\section{Good Corporate Governance}

Menurut Sukrisno, (2013) GCG diartikan sebagai sistem yang mengatur hubungan peran antara dewan komisaris, direksi, pemegang saham dan pemangku kepentingan lainnya dimana terdapat suatu proses yang transparan dalam penentuan tujuan, pencapaian serta penilaian kinerja perusahaan.

\section{Komisaris Independen}

Sebagaimana yang dijelaskan oleh Putra \& Merkusiwati, (2016) mengenai komisaris independen sebagai pihak yang tidak terafiliasi oleh pihak manapun dari segi struktur kepemimpinan serta kepemilikan perusahaan dalam rangka pengawasan dan pengarahan mengenai kebijakan perusahaan apakah sudah memenuhi ketentuan-ketentuan yang berlaku.

\section{Komite Audit}

Dijabarkan dalam Peraturan OJK Nomor 55 / POJK.04 / 2015 yang diartikan sebagai komite yang dibentuk dewan komisaris dengan anggota paling sedikit berjumlah 3 orang dalam membantu pelaksanaan tugas dewan komisaris berkaitan menelaah resiko yang mungkin dihadapi perusahaan juga bagaimana mematuhi peraturan yang ada. 


\section{Capital Intensity}

Capital intensity mencerminkan seberapa besar jumlah modal perusahaan yang tertanam dalam bentuk aset tetap dan persediaan (Putra \& Merkusiwati, 2016). Keberadaan aset tetap umumnya diikuti dengan munculnya beban depresiasi, yang dalam lingkup perpajakan beban tersebut dapat digunakan sebagai pengurang atas laba yang dilaporkan (Syamsuddin \& Suryarini, 2019).

\section{Leverage}

Leverage menunjukkan besarnya hutang yang digunakan untuk pembiayaan perusahaan dalam menjalankan aktivitas operasinya (Praditasari \& Setiawan, 2017). Beban bunga timbul dari hutang sebagai sumber pendanaan eksternal perusahaan yang disisi lain dapat dimanfaatkan sebagai pengurang pendapatan. Besarnya nominal beban tersebut cenderung dijadikan sebagai suatu taktik dalam hal meminimalkan beban pajak (Anindyka, 2018).

\section{Profitabilitas}

Dewinta \& Setiawan, (2016) mengartikan profitabilitas sebagai cara untuk mengetahui bagaimana kemampuan perusahaan dalam memperoleh profit atas operasional perusahaan selama periode tertentu pada tingkat penjualan, aset, dan modal saham tertentu. Seiring meningkatnya laba maka nominal beban pajak juga mengalami peningkatan, sehingga manajer akan berusahan menekan beban pajak dengan salah satunya melakukan tax avoidance.

\section{Beban Iklan}

Sesuai Peraturan Menteri Keuangan Nomor 2/ PKM.03 /2010 bahwa beban iklan berkaitan dengan biaya yang dikeluarkan perusahaan untuk membayar iklan atau promosi dalam rangka memperkenalkan produknya kepada masyarakat luas. Besarnya beban iklan yang dikeluarkan dapat dimanfaatkan sebagai pengurang laba sehingga dapat menekan penghasilan kena pajak (Novitasari dan Suharni, 2019).

\section{Pengembangan Hipotesis}

Alfina, et al., (2018) menemukan bukti adanya pengaruh komisaris indepeden pada tax avoidance. Dari hasil penelitiannya dijelaskan keberadaan komisaris independen berkaitan dengan pengawasan dan pengarahan mengenai kebijakan perusahaan apakah sudah memenuhi ketentuan-ketentuan yang berlaku. Sehingga seiring meningkatnya kuantitas dari komisaris independen berdampak pada kualitas dalam memberikan pengawasan dan kontrol yang ketat terhadap kinerja manajemen. Namun Syamsuddin \& Suryarini, (2019) tidak mendukung temuan ini. Maka ditariklah hipotesis:

\section{H1: Komisaris independen berpengaruh pada tax avoidance}

Penelitian oleh Lestari, et al., (2018) membuktikan komite audit mempengaruhi tax avoidance. Diterangkan pada Peraturan OJK Nomor 55 /POJK.04/2015 bahwa keanggotaan komite audit paling sedikit 3 orang. Implikasi atas aturan tersebut bahwa meningkatnya kuantitas anggota berdampak pada kualitas GCG yang semakin baik, sehingga akan menurunkan terjadinya tindakan tax avoidance. Berbeda dengan Praditasari \& Setiawan, (2017) memiliki bukti komite audit tidak berpengaruh terhadap penghindaran pajak. Maka ditariklah hipotesis:

\section{H2: Komite audit berpengaruh pada tax avoidance}

Anindyka, et al., (2018) membuktikan capital intensity mempengaruhi tax avoidance. Aset tetap yang dimiliki perusahaan umumnya bernilai besar yang mana dalam kepemilikan tersebut memunculkan adanya beban depresiasi. Dalam lingkup perpajakan memperbolehkan laba yang akan dilaporkan dikurangi dengan beban depresiasi. Sehingga semakin tingginya nilai intensitas aset tetap mengindikasikan perusahaan lebih rentan melakukan tindakan penghindaran pajak, sementara Syamsuddin \& Suryarini, (2019) menunjukkan hasil yang sebaliknya. Maka ditariklah hipotesis:

\section{H3: Capital intensity berpengaruh pada tax avoidance}

Temuan Praditasari \& Setiawan, (2017) bahwa tingginya rasio leverage mempengaruhi tax avoidance. Hal ini didasarkan pada besarnya nominal beban bunga dari hutang yang bisa mengurangi pendapatan sehingga beban pajak dapat diminimalkan. Temuan tersebut tidak didukung penelitian dari Yulyanah dan Kusumastuti (2019). Maka ditariklah hipotesis:

\section{H4: Leverage berpengaruh pada tax avoidance}

Layaknya temuan Astuti, et al., (2018) bahwa tingginya angka profitabilitas menunjukkan peningkatan pendapatan perusahaan yang diikuti dengan besarnya pajak penghasilan terutang. Sehingga memicu untuk melakukan praktik penghindaran pajak guna mempertahankan besarnya pendapatan tersebut. Sementara temuan Puspita, et al., (2018) tax avoidance tidak dipengaruhi profitabilitas. Maka ditariklah hipotesis: 


\section{H5: Profitabilitas berpengaruh pada tax avoidance}

Penelitian Sugitha \& Supadmi, (2016) menemukan adanya pengaruh beban iklan terhadap terhadap tax avoidance. Dalam Peraturan Menteri Keuangan Nomor. 2/PKM.03/2010 menguraikan mengenai apa saja yang tergolong dalam beban promosi yang nantinya dapat dipakai sebagai pengurang penghasilan bruto. Implikasi dari aturan tersebut seolah menggiring perusahaan agar memanfaatkan kesempatan untuk menekan pembayaran pajak dengan menggunakan beban iklan. Novitasari \& Suharni, (2019) memiliki pendapat berbeda bahwa penghindaran pajak tidak dipengaruhi oleh beban iklan. Maka ditariklah hipotesis:

H6 : Beban iklan berpengaruh pada tax avoidance

\section{METODE}

Penelitian ini merupakan penelitian kuantitatif menggunakan data sekunder laporan keuangan yang diperoleh melalui situs www.idx.co.id serta website resmi perusahaan terkait. Populasi perusahaan industri barang konsumsi yang terdaftar di BEI tahun 2014-2018. Teknik pengambilan sampel dengan purposive sampling. Kriteria pengambilan sampel sebagai berikut: (1) menerbitkan laporan keuangan tahunan secara lengkap dari tahun 2014-2018; (2) tidak mengalami kerugian selama periode pengamatan; dan (3) memiliki kelengkapan data terkait penelitian. Metode analisis regresi data panel. dengan Eviews versi 9 dengan rumus model: $\mathrm{Y}=\mathrm{c}+\mathrm{b} 1 \mathrm{X} 1 \mathrm{ti}+\mathrm{b} 2 \mathrm{X} 2 \mathrm{ti}+\mathrm{b} 3 \mathrm{X} 3 \mathrm{ti}+$ $\mathrm{b} 4 \mathrm{X} 4 \mathrm{ti}+\mathrm{b} 5 \mathrm{X} 5 \mathrm{ti}+\mathrm{b} 6 \mathrm{X} 6 \mathrm{ti}+\mathrm{e}$

Keterangan: $\mathrm{Y}=$ Tax avoidance $; \mathrm{C}=$ Konstanta; $\mathrm{X} 1=$ Komisaris independen; $\mathrm{X} 2=$ Komite audit $\mathrm{X} 3=$ Capital intensity: $\mathrm{X} 4=$ Leverage $; \mathrm{X} 5$ = Profitabilitas; X6 = Beban iklan; $\mathrm{e}=$ Error Term $; \mathrm{t}=\mathrm{Waktu} ; \mathrm{i}=$ Sampel Perusahaan

\section{HASIL}

Tabel 2

Proses Pemilihan Sampel

\begin{tabular}{llr}
\hline No & \multicolumn{1}{c}{ Keterangan } & Jumlah \\
\hline 1 & Perusahaan industri barang konsumsi terdaftar di BEI tahun 2014-2018 & 38 \\
2 & Menerbitkan laporan keuangan tahunan secara tidak lengkap & $(1)$ \\
3 & Mengalami kerugian selama periode pengamatan & $(11)$ \\
4 & Tidak memiliki kelengkapan data terkait penelitian & $(3)$ \\
& Jumlah sampel yang memenuhi kriteria & 23 \\
& Periode pengamatan & 5 \\
& Jumlah data pengamatan & 115 \\
\hline
\end{tabular}

Sumber : Data Diolah

TABEL 3. Hasil Analisis Statistik Deskriptif

\begin{tabular}{lcccc}
\hline \multicolumn{1}{c}{ Variabel } & \multicolumn{1}{c}{ Mean } & Maximum & Minimum & Std. Deviasi \\
\hline Tax Avoidance & 0.259009 & 0.596000 & 0.066000 & 0.051239 \\
Komisaris Independen & 0.419852 & 0.800000 & 0.333000 & 0.113593 \\
Komite Audit & 3.086957 & 4.000000 & 2.000000 & 0.312467 \\
Capital Intensity & 0.356591 & 0.784000 & 0.059000 & 0.150498 \\
Leverage & 0.779652 & 3.029000 & 0.074000 & 0.603360 \\
Profitabilitas & 0.140226 & 0.921000 & 0.006000 & 0.132187 \\
Beban Iklan & 0.064296 & 0.191000 & 0.001000 & 0.048085 \\
\hline
\end{tabular}

Sumber :Data Diolah (2019)

Pengujian Model Regresi Data Panel

Tabel 4

Fixed Effect Model

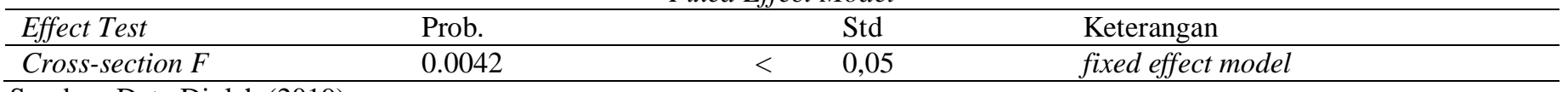

Sumber: Data Diolah (2019) 
Tabel 4 dapat diketahui model fixed effect lebih baik dari common effect karena prob. 0.0042 lebih kecil dari sig. 0,05 sehingga diperlukan pengujian lagi untuk menentukan apakah fixed effect model atau random effect model dengan uji hausman.

Tabel 5

Hasil Uji Hausman

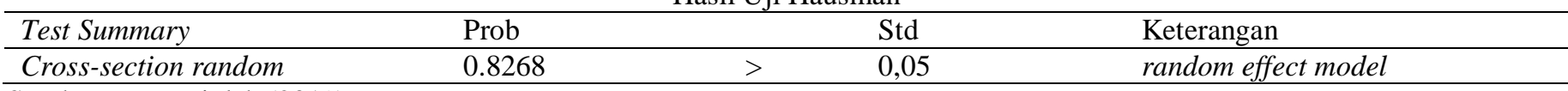

Sumber: Data Diolah (2019)

Tabel 5 memperlihatkan prob. senilai 0.8268 lebih besar dibanding nilai sig. 0,05 yang berarti random effect model lebih baik digunakan. Langkah selanjutnya menentukan apakah random effect model lebih baik dari pada common effect model dengan melakukan uji Lagrange Multiplier (LM).

Tabel 6

Hasil Uji Lagrange Multiplier (LM)

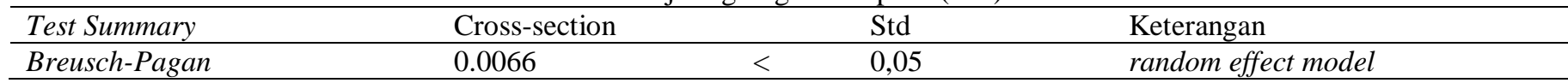

Sumber: Data Diolah (2019)

Hasil uji LM membuktikan nilai Breusch-Pagan 0.0066 lebih kecil dibandingkan signifikansi 0,05 maka model regresi random effect lebih tepat serta dipakai ke tahap berikutnya. Sebagaimana telah dijelaskan oleh Gujarati $\&$ Porter (2009) bahwa model estimasi yang menggunakan random effect, maka uji asumsi klasik tidak diperlukan.

Tabel 7.

Hasil Uji Regresi

\begin{tabular}{lrr}
\hline Variabel & Coefficient & Sig \\
\hline C & 0.32714 & - \\
Komisaris Independen & -0.027152 & $<0,05$ \\
Komite Audit & -0.009991 & $<0,05$ \\
Capital Intensity & -0.084981 & $<0,05$ \\
Leverage & 0.036489 & $<0,05$ \\
Profitabilitas & -0.107046 & $<0,05$ \\
Beban Iklan & -0.140351 & $<0,05$ \\
\hline
\end{tabular}

Sumber: Data Diolah (2019)

Persamaan model regresi data panel dari hasil random effect diperoleh persamaan:

Yit $=0.32714-0.027152 \mathrm{X} 1-0.009991 \mathrm{X} 2-0.084981 \mathrm{X} 3+0.036489 \mathrm{X} 4-0.107046 \mathrm{X} 5-0.140351 \mathrm{X} 6$

a. Konstanta sebesar 0.32714 artinya tax avoidance akan bernilai 0.303792 jika komisaris independen, komite audit, capital intensity, leverage, profitabilitas, dan beban iklan bernilai tetap atau 0 (nol).

b. Komisaris independen bernilai - 0.027152. Diartikan setiap kenaikan 1\% komisaris independen maka -0.027152 nilai tax avoidance akan turun dengan perkiraan variabel lainnya bernilai tetap.

c. Komite audit sebesar -0.009991 . Berarti saat $1 \%$ kenaikan komite audit maka nilai tax avoidance akan turun 0.009991 dengan asumsi variabel lain nilainya tetap.

d. Capital intensity bernilai -0.084981. Maknanya setiap variabel intensitas aset tetap naik $1 \%$, maka tax avoidance akan turun -0.084981 dengan perkiraan variabel lainnya bernilai tetap.

e. Leverage bernilai 0.036489. Hal ini mengandung arti jika setiap kenaikan $1 \%$ leverage maka nilai tax avoidance akan naik sebesar 0.036489 sementara variabel lain bernilai tetap.

f. Variabel profitabilitas sebesar -0.107046. Setiap kenaikan profitabilitas $1 \%$ maka -0.107046 nilai tax avoidance akan turun, dianggap variabel lainnya bernilai tetap.

g. Beban iklan -0.140351. Diartikan jika beban iklan naik $1 \%$ berdampak pada nilai tax avoidance yang turun sebesar -0.140351 dengan asumsi nilai variabel lain tetap.

Tabel 8.

Hasil Uji Kelayakan Model

\begin{tabular}{llll}
\hline Model & Prob $(F$ statistic $)$ & Standar & Keterangan \\
\hline Regresi data panel & 0,036282 & $<0,05$ & Model Layak
\end{tabular}


Sesuai tabel 8 dapat dilihat bahwa nilai prob. (F statistic) $0,036282<$ dari 0,05 maka dapat diberikan kesimpulan bahwa model regresi yang diestimasi layak digunakan untuk menjelaskan pengaruh komisaris independen, komite audit, capital intensity, leverage, profitabilitas, dan beban iklan terhadap tax avoidance.

TABEL 9. Hasil Uji Hipotesis (Uji t)

\begin{tabular}{lccccl}
\hline \multicolumn{1}{c}{ Variabel } & t-Statistic & t-Tabel & Prob. & Standar & Kesimpulan \\
\hline Komisaris Independen & -0.407011 & -1.981 & 0.6848 & $<0,05$ & Ditolak \\
Komite Audit & -0.547344 & -1.981 & 0.5853 & $<0,05$ & Ditolak \\
Capital Intensity & -1.671374 & -1.981 & 0.0975 & $<0,05$ & Ditolak \\
Leverage & 2.895777 & 1.981 & 0.0046 & $<0,05$ & Diterima \\
Profitabilitas & -2.104654 & -1.981 & 0.0376 & $<0,05$ & Diterima \\
Beban Iklan & -0.989155 & -1.981 & 0.3248 & $<0,05$ & Ditolak \\
\hline
\end{tabular}

Sumber :Data Diolah (2019)

Berdasarkan tabel 9 diketahui bahwa nilai dari komisaris independen, $-\mathrm{t}_{\text {hitung }}>-\mathrm{t}_{\mathrm{tabel}}$ $(-0,407011>-1,981)$ dan prob. 0,6848 $>0,05$. Sehingga $\mathrm{H} 1$ yang menyatakan komisaris independen berpengaruh pada tax avoidance ditolak. Nilai dari komite audit, $-\mathrm{t}_{\text {hitung }}>-\mathrm{t}_{\text {tabel }}(-0,547344>-1,981)$ dan prob. 0,5853 $>0,05$ artinya H2 komite audit berpengaruh terhadap tax avoidance dinyatakan ditolak. Nilai dari capital intensity, $-\mathrm{t}_{\text {hitung }}>-\mathrm{t}_{\mathrm{tabel}}(-1,671374>-1,981)$ dan prob. 0,0975 > 0,05 artinya H3 yang menyatakan capital intensity berpengaruh terhadap tax avoidance dinyatakan ditolak. Nilai dari leverage, $\mathrm{t}_{\text {hitung }}>\mathrm{t}_{\text {tabel }}(2,895777>1,981)$ dan prob. $0,0046<0,05$ artinya $\mathrm{H} 4$ yang menyatakan leverage berpengaruh terhadap tax avoidance dinyatakan diterima. Nilai dari profitabilitas, $-\mathrm{t}_{\mathrm{hitung}}<-\mathrm{t}_{\mathrm{tabel}}$ $(-2,104654<-1,981)$ dan prob. $0,0376<0,05$ artinya $\mathrm{H} 5$ yang menyatakan profitabilitas berpengaruh terhadap tax avoidance dinyatakan diterima. Nilai dari beban iklan, $-\mathrm{t}_{\text {hitung }}>-\mathrm{t}_{\text {tabel }}(-0,989155>-1,981)$ dan prob. $0,3248>0,05$ artinya H6 yang menyatakan beban iklan berpengaruh terhadap tax avoidance dinyatakan ditolak.

Tabel 10.

Hasil Uji Koefisien Determinasi

Adjusted. R-squared Keterangan

$0.066053 \quad$ Berpengaruh 6,605\%

Sumber: Data Diolah (2019)

Tabel 10 dapat diketahui komisaris independen, komite audit, capital intensity, leverage, profitabilitas dan beban iklan dapat menjelaskan tax avoidance sebesar 6,605\% sementara dipengaruhi sebab-sebab lain diluar regresi sebesar 93,395\%. Hasil dari uji hipotesis pertama memperlihatkan tidak adanya pengaruh komisaris independen terhadap tindakan tax avoidance, sehingga H1 dinyatakan ditolak. Banyak sedikitnya jumlah dari komisaris independen tidak mempengaruhi adanya tindakan penghindaran pajak, karena dengan ditambahnya anggota hanya sebagai formalitas dalam memenuhi ketentuan peraturan serta sebatas simbol dari penerapan GCG. Temuan ini mendukung Syamsuddin \& Suryarini (2019), namun berbeda dengan hasil dari Alfina, et al., (2018) bahwa banyaknya komisaris independen mampu mempengaruhi tax avoidance. Hasil pengujian hipotesis membuktikan komite audit tidak mempengaruhi tax avoidance, sehingga $\mathrm{H} 2$ dinyatakan ditolak. Temuan ini sejalan dengan bukti penelitian Praditasari \& Setiawan (2017). Banyaknya anggota komite audit tidak mampu mempengaruhi tindakan penghindaran pajak. Proporsi jumlah komite audit sebatas bagaimana perusahaan menaati peraturan serta bukti atas penerapan good corporate governance. Sedangkan kaitannya dengan upaya menekan praktek penghindaran pajak, tidak hanya mengenai jumlah keanggotaannya saja melainkan bagaimana kualitas dalam pelaksanaan tugas komite audit. Lestari, et al., (2018) memiliki hasil sebaliknya yang menyatakan tax avoidance dipengaruhi oleh komite audit.

Pada pengujian hipotesis menemukan hasil tidak adanya pengaruh capital intensity terhadap tax avoidance, sehingga H3 ditolak. Hal ini sejalan dengan bukti penelitian Riantami \& Triyanto, (2018). Banyak atau sedikitnya aset tetap yang dimiliki perusahaan tidak berpengaruh terhadap tindakan penghindaran pajak. Adanya penambahan aset tetap setiap tahun dalam rangka memenuhi kebutuhan operasional produksi, bukan dimaksudkan untuk menghindari pajak. Temuan ini tidak sejalan dengan temuan Anindyka, et al., (2018) bahwa capital intensity berpengaruh terhadap tax avoidance. Uji hipotesis keempat diperoleh hasil adanya pengaruh leverage terhadap tax avoidance, sehingga $\mathrm{H} 4$ dinyatakan diterima. Perusahaan yang memiliki hutang memanfaatkan beban bunga atas hutang tersebut untuk mengurangi penghasilan bruto sehingga dapat meminimalkan beban pajaknya. Hasil ini sejalan dengan Praditasari \& Setiawan, (2017). Besarnya bunga atas hutang yang dapat dikurangkan dari penghasilan bruto berdasarkan perbandingan antara hutang dan modal paling tinggi $4: 1$ (empat banding satu ) berdasarkan Peraturan Direktur 
Jenderal Pajak Nomor PER-25/PJ/2017 pasal 2. Perusahaaan memanfaatkan besarnya toleransi beban bunga pinjaman tersebut untuk mengurangi beban pajaknya seolah mengindikasikan adanya upaya tindakan tax avoidance. Hasil ini tidak konsisten dengan penelitian Yulyanah \& Kusumastuti, (2019) bahwa leverage tidak berpengaruh pada tax avoidance. Hipotesis kelima terbukti bahwa profitabilitas menunjukkan adanya pengaruh pada tax avoidance, sehingga H5 dinyatakan diterima dan mendukung temuan Hidayat, (2018). Berdasarkan hasil penelitian pada perusahaan sampel membuktikan semakin tinggi laba perusahaan maka tingkat penghindaran pajak semakin rendah.

Hal ini dikarenakan dengan semakin tingginya laba maka perusahaan memiliki kemampuan untuk melakukan pembayaran pajak, bahkan dengan profit yang tinggi perusahaan dengan mudahnya melakukan pengaturan laba (Hidayat, 2018). Berbeda dengan perusahaan yang memiliki tingkat laba rendah umumnya mengalami kesulitan keuangan dan cenderung melakukan penghindaran pajak. Hasil ini tidak sejalan dengan Astuti, et al., (2018) bahwa profitabilitas berpengaruh positif pada tax avoidance. Sementara Puspita, et al., (2018) bahwa profitabilitas tidak berpengaruh pada tax avoidance. Pada uji hipotesis keenam didapat hasil tidak adanya pengaruh beban iklan pada praktik penghindaran pajak, sehingga H6 ditolak. Penelitian ini memperlihatkan semakin besar nominal beban iklan yang dikeluarkan tidak untuk tujuan dimanfaatkan sebagai pengurang beban pajak semata. Perusahaan memasang iklan dengan maksud untuk membangun "brand image" sehingga semakin besar intensitas iklan yang dilakukan perusahaan secara tidak langsung mendapat sorotan serta mempunyai reputasi baik serta sehingga kecenderungan melakukan penghindaran pajak menurun (Fatmawati \& Solikin, 2017). Disimpulkan besarnya beban iklan tidak dapat mengindikasikan bahwa perusahaan melakukan penghindaran pajak. Temuan ini sejalan dengan penelitian Novitasari \& Suharni, (2019) namun tidak mendukung hasil dari Sugitha \& Supadmi, (2016) mengenai beban iklan yang tinggi berpengaruh pada tingkat penghindaran pajak.

\section{SIMPULAN}

Hasil pengujian hipotesis membuktikan leverage dan profitabilitas berpengaruh pada tax avoidance, sedangkan komisaris independen, komite audit, capital intensity dan beban iklan tidak mempengaruhi tax avoidance. Banyak sedikitnya anggota komisaris independen dan komite audit tidak mempengaruhi adanya tindakan tax avoidance. Sedangkan beban bunga yang timbul atas hutang dimanfaatkan perusahaan untuk mengurangi penghasilan bruto guna menekan besarnya beban pajak, seolah mengindikasikan terjadinya tax avoidance. Sementara tingginya laba menunjukkan kemampuan perusahaan dalam pembayaran pajak sehingga berdampak menurunnya tindakan penghindaran pajak. Adanya beban depresiasi atas kepemilikan aset tetap serta beban iklan tidak dimanfaatkan sebagai taktik untuk menekan pembayaran pajak, melainkan digunakan untuk menunjang kegiatan operasional perusahaan.

\section{DAFTAR PUSTAKA}

Alfina, I. T., Nurlaela, S., \& Wijayanti, A. (2018). The Influence of Profitability, Leverage, Independent Comiissioner, and Company Size to Tax Avoidance. The 2nd International Conference on Technology, Education, and Social Science 2018(The 2nd ICTESS 2018), (pp. 102-106).

Alfisyah, T. N., Suhendro, \& Masitoh, E. (2018). Tax Avoidance Ditinjau Dari Capital Intensity Ratio, Beban Iklan Perusahaan, Kompensasi Rugi Fiskal (Studi Pada Perusahaan Perbankan Yang Terdaftar Di BEI Tahun 20152017). 1-10.

Anindyka S, D., Pratomo, D., \& Kurnia. (2018). Pengaruh Leverage (DAR), Capital Intensity dan Inventory. $e$ Proceeding of Management: Vol.5, No.1 Maret .

Astuti, M. T., Titisari, K. H., \& Nurlaela, S. (2018). Pengaruh Karakteristik Tata Kelola Perusahaan dan Kinerja Perusahaan terhadap Tax Avoidance (Studi Empiris Pada Perusahaan Makanan Minuman yang Terdaftar di Bursa Efek Indonesia Tahun 2012-2015). The 2nd International Conference on Technology, Education, and Social Science 2018 (The 2nd ICTESS 2018).

BIBLIOGRAPHY Yulyanah, \& Kusumastuti, S. Y. (2019). Tax Avoidance Pada Perusahaan Manufaktur Sektor Industri Barang dan Konsumsi Sub Sektor Makanan dan Minuman Yang Terdaftar Di Bursa Efek Indonesia. Media Ekonomi Vol 27 No 1 April, 17-36.

Dewinta, I. A., \& Setiawan, P. E. (2016). Pengaruh Ukuran Perusahaan, Umur Perusahaan, Profitabilitas, Leverage dan Pertumbuhan Penjualan Terhadap Tax Avoidance. E-Jurnal Akuntansi Universitas Udayana Vol 14.3 Maret, 1584-1613.

Dyreng, S., Michelle, H., \& Edward, L. (2010). The Effect of Excecutives on Corporate Tax Avoidance . The Accounting Review Vol $85,1163-1189$.

Fatmawati, O. R., \& Solikin, A. (2017). Pengaruh Karakteristik Perusahaan dan Beban Iklan Terhadap Tindakan Penghindaran Pajak Pada Perusahaan Manufaktur. Jurnal Substansi Vol 1 No 1, 123-141.

Hidayat, W. W. (2018). Pengaruh Profitabilitas, Leverage, Pertumbuhan Penjualan Terhadap Penghindaran Pajak : Studi Kasus Perusahaan Manufaktur di Indonesia. Jurnal Riset Manajemen dan Bisnis (JRMB) FE UNIAT Vol 3 No 1 Februari , 19-26. 
Laporan Tahunan Kinerja Direktorat Jenderal Pajak. (2019).

Laporan Tahunan Kinerja Kementerian Perindustrian. (2018).

Lestari, P., Harimurti, F., \& Suharno. (2018). Pengaruh Karakteristik Perusahaan dan Sales Growth Terhadap Tax Avoidance (Studi Kasus Pada Perusahaan Manufaktur Sektor Makanan dan Minuman YangTerdaftar di BEI Tahun 2013-2016). Jurnal Akuntansi dan Sistem Teknologi Informasi Vol 14 No 4 Desember, 551-559.

Novitasari, M., \& Suharni, S. (2019). Implikasi Indikator Keuangan Terhadap Tax Avoidance. AFRE Accounting and Financial Review Vol. 2 (1), 16-23.

Peraturan Direktur Jenderal Pajak No PER/25/PJ/2017 Tentang Pelaksanaan Penentuan Besarnya Perbandingan Antara Hutang dan Modal Perusahaan Untuk Keperluan Penghitungan Pajak Penghasilan dan Tata Cara Pelaporan Hutang Swasta Luar Negeri.

Peraturan Menteri Keuangan No 2/PKM.03/2010 Tentang Biaya Promosi Yang Dapat Dikurangkan Dari Penghasilan Bruto.

Peraturan Otoritas Jasa Keuangan No 55/POJK.04/2015 Tentang Pembentukan dan Pedoman Pelaksanaan Kerja Komite Audit .

Praditasari, N. K., \& Setiawan, P. E. (2017). Pengaruh Good Corporate Governance, Ukuran Perusahaan, Leverage Dan Profitabilitas Pada Tax Avoidance. E-Jurnal Akuntansi Universitas Udayana Vol.19 No.2 , 29-58.

Puspita, E. R., Nurlaela, S., \& Masitoh, E. (2018). Pengaruh Size, Debts, Intangible Assets, Profitability, Multinationality dan Sales Growth Terhadap Tax Avoidance. Seminar Nasional dan Call for Paper;Manajemen, Akuntansi dan Perbankan 2018.

Putra, I. G., \& Merkusiwati, N. K. (2016). Pengaruh Komisaris Independen, Leverage, Size, dan Capital Intensity Ratio Pada Tax Avoidance. E-Jurnal Akuntansi Universitas Udayana Vol 17 Oktober, 690-714.

Riantami, V. L., \& Triyatno, D. N. (2018). Pengaruh Proporsi Komisaris Independen, Financial Distress, Intensitas Aset Tetap, dan Pertumbuhan Penjualan Terhadap Tax Avoidance. Jurnal AKSARA PUBLIC Vol 2 No 4 Edisi Desember, 23-35.

Sugitha, I. M., \& Supadmi, N. L. (2016). Pengaruh Karakteristik Perusahaan dan Beban Iklan Pada Tindakan Penghindaran Pajak. E-Jurnal Akuntansi Universitas Udayana Vol 17 No 2 November, 1311-1341.

Sukrisno, A. (2013). Auditing Petunjuk Praktis Pemeriksaan Akuntan Oleh Akuntan Publik Edisi 4 Buku 1. Jakarta: Salemba Empat. 